Article

\title{
Environmental Life Cycle Assessment of Refrigerator Modelled with Application of Various Electricity Mixes and Technologies
}

\author{
Anna Lewandowska ${ }^{1, *}$, Przemysław Kurczewski ${ }^{2}$, Katarzyna Joachimiak-Lechman ${ }^{1} \mathbb{D}$ and Marek Zabłocki ${ }^{2}$ \\ 1 Department of Quality Management, Poznań University of Economics and Business, 61-875 Poznan, Poland; \\ katarzyna.joachimiak-lechman@ue.poznan.pl \\ 2 Faculty of Civil and Transport Engineering, Poznan University of Technology, Piotrowo 3, \\ 60-965 Poznan, Poland; przemyslaw.kurczewski@put.poznan.pl (P.K.); marek.zablocki@put.poznan.pl (M.Z.) \\ * Correspondence: anna.lewandowska@ue.poznan.pl
}

check for

updates

Citation: Lewandowska, A.;

Kurczewski, P.;

Joachimiak-Lechman, K.; Zabłocki, M.

Environmental Life Cycle Assessment

of Refrigerator Modelled with

Application of Various Electricity

Mixes and Technologies. Energies

2021, 14, 5350. https://doi.org/

$10.3390 /$ en 14175350

Academic Editors: Marek Dudek,

Joanna Kulczycka and Sergio Ulgiati

Received: 19 June 2021

Accepted: 25 August 2021

Published: 27 August 2021

Publisher's Note: MDPI stays neutral with regard to jurisdictional claims in published maps and institutional affiliations.

Copyright: (c) 2021 by the authors. Licensee MDPI, Basel, Switzerland. This article is an open access article distributed under the terms and conditions of the Creative Commons Attribution (CC BY) license (https:/ / creativecommons.org/licenses/by/ $4.0 /)$.

\begin{abstract}
Improving national electricity mixes and increasing a share of renewable energy covered by credible and reliable tracking systems are vital topics, also in a context of life cycle assessment. There are many publications devoted to the relevance of energy in the life cycle of products, but only few LCA examples applying residual mixes have been found in the literature. The paper presents the results of an LCA study for a refrigerator calculated with using different electricity mixes and technologies. The life cycle was divided into eight stages and the electricity consumption was modelled as renewable energy, national residual mix, or national supplier mix. Electricity mixes for three different countries were selected and used. The study aimed to answer the following questions: "what are the most relevant elements in the life cycle of the analysed refrigerator?", "do the elements change if various electricity mixes are applied?", and "what differences are there in the environmental impact of electricity generation modelled as residual and supplier mixes?". From the life cycle perspective, not only may differences in national electricity systems between countries turn out to be important, but equally significant may be the choice between different types of mixes for a certain country.
\end{abstract}

Keywords: energy; life cycle management; environmental relevance

\section{Introduction}

For many years, life cycle and life cycle environmental assessment (LCA) methods have been used to assess the environmental impact of products and organisations. The characteristic features of these tools lie in combining the input and output material and energy streams occurring in the product system that are necessary to perform the function defined in the functional unit. Only by taking into account the life cycle perspective is a reliable comparison possible between the different ways of performing the same function. One of the most common and often most important aspects in the product life cycle consists of the need to cover electricity and heat demand. This is often identified as one of the most significant issues. The final result of the life cycle analysis accounts for the effects resulting from both direct and indirect energy consumption. The environmental impact of generating electricity and heat varies depending on the energy carriers and the technology used, but it can generally be assumed to have a complex multi-faceted nature. On the one hand, it covers the depletion of resources (often non-renewable), water consumption (e.g., for cooling turbines in power plants), but also involves emissions to the atmosphere (e.g., greenhouse gases, acidifying compounds, dust) or emissions to water (e.g., metals). Moreover, as a rule, energy consumption applies to every life cycle stage, as it often occurs during the extraction or acquisition of raw materials (e.g., mines, refineries, recycling of secondary raw materials), in-process at suppliers (e.g., steelworks, semi-finished products and ancillary materials), transport, final product manufacture, distribution (transport and storage in distribution centres), sales, use, and end of life. Because energy constitutes 
an important element of many life cycle assessments, it is especially important to model this aspect in a way that properly addresses the goal and scope of the study. Modelling choices should reflect the decisional context of the study and may be differentiated between attributional and consequential scenarios [1]. The attributional LCA is descriptive by nature and, according to Finnveden et al. [2], it is focused on 'describing the environmentally relevant physical flows to and from a life cycle and its subsystems'. The consequential LCA is change-oriented and aimed at 'describing how environmentally relevant flows will change in response to possible decisions' [2]. The modelling considerations are among the most essential developments in LCA [2] and have been discussed by some authors also in the context of energy. Frischknecht \& Stucki [3] used energy-oriented examples to indicate the scale of potential consequences of decisions and the relative economic size of objects of investigation as important drivers for selecting the most suitable inventory model. They showed significant differences in the environmental impact of electricity supply mixes modelled according to attributional and long-term decisional approaches [3]. Vandepaer et al. [4] focused on the change-oriented approach and presented the results of the generation and integration of long-term marginal electricity supply mixes to the Ecoinvent database v. 3.4. The attributional and consequential choices have been discussed in the context of electricity also by Schmidt et al. [5] and Jones et al. [6].

Besides modelling choices, another interesting aspect is the relevance of energy in the life cycle of products. This depends not only on the modelling scenario, but also on the characteristics of products (e.g., active vs. passive products) and the energy generation technology. This question is important from the perspective of manufacturers and the locations of upstream and downstream processes, as power systems differ between countries, and generating $1 \mathrm{kWh}$ of electricity in a different geographical location may entail a different environmental impact $[7,8]$. As a consequence, for producers of certain products (e.g., electrical and electronic equipment), it is the distribution and export structure and, thus, the energy mixes of the countries where the equipment is sold and used that may be significant for the outcome of the LCA study. These are, thus, elements that affect the environmental performance of products and also, potentially, their competitiveness. In this article, an attempt is made to answer the question of whether and to what extent the geographical location of the various life cycle stages and the associated consumption of electric power from the grid may affect the environmental impact assessment of the selected product. In Section 2, the results of a literature review and some examples of LCA case studies for products representing different product categories are presented. The relevance of energy in the life cycle of the products is indicated. The following sections are aimed at presenting assumptions, inventory data, and impact assessment results for the life cycle of a refrigerator. Various locations for suppliers' activity and country-specific electricity mixes have been assumed for the selected construction materials. Furthermore, downstream stages, i.e., distribution, retail, use, and end of life (EOL), are taken into account and modelled with different geographical locations and technologies for electricity generation. The choice of the locations is hypothetical. We selected countries that feature visibly different national electricity mixes.

Our contribution is to provide the results of the LCA analysis obtained using residual electricity mixes. This may be recognised as a kind of novel, as only few LCA case studies applying residual mixes have been found in the literature [9]. There are many publications devoted to the relevance of energy in the life cycle of products, but these usually use production or consumption national mixes, where tracked and untracked electricity is included. It may be expected that the importance of using residual mixes-with only untracked electricity included-will grow, e.g., in the context of specific calculation rules to be applied in the fields of Environmental Product Declarations (EPD) [10] and Environmental Footprint of Products (PEF) [11]. This is the reason for which a provision of LCA case studies modelled with residual mixes may be recognised as vital and deserving of attention. The target audience of our paper are people involved in the life-cycle-based 
environmental improvement of energy-related products: eco-designers, green marketing specialists, technologists, and environmental management systems managers.

\section{Relevance of Energy in the Life Cycle of Different Products}

Whether energy modelling and the modelling degree influence the results of an LCA analysis depends on the importance of energy throughout the life cycle and whether it is one of the most relevant issues. The share of energy may vary depending on the characteristics of products, which are broadly classified into active (requiring an energy supply for their functioning) and passive (not requiring a direct energy supply for their functioning), and the type of energy used. From the point of view of product characteristics, products kept in operation for long periods are the most obvious examples of active products. In this case, operation is often identified as the most relevant life cycle stage. Examples include electrical and electronic equipment [12-14] and buildings [8,14-16]. On a macro scale, the environmental significance of the use stage of such products is illustrated by the results of the Environmental Impact of Products (EIPRO) project implemented by JRC, ESTO, and IPTS [17]. They showed that the activities that are most environmentally intensive from the point of view of final consumption in the European Union economy (top 35) included heating (use of heating equipment), transport (use of means of transport) and the use of various types of household appliances [17]. The fact that these products rank so highly (across various impact categories) can be mainly linked to the production and supply of the heat or electricity necessary for the realisation of multiannual use periods.

However, if we look at the results of the EIPRO project [17], it turns out that the top 35 include not merely products powered directly with energy. Other product categories, including food, are also listed. As shown by examples of LCA studies for food [18,19], the so-called "cradles" and farm activities particularly gain importance in their case, with especially critical items being the production of animal feed, the production and use of fertilisers, biogenic emissions from animal digestive processes, water consumption for irrigation of fields, or soil conversion. However, it must not be overlooked that the farm also consumes energy for transport and heating purposes, and energy is also used in the feed, fertiliser, or plant protection chains. Moreover, processed food often requires refrigerators or freezers (e.g., dairy, frozen products), which translates into additional energy demand for transport and storage (at the stages of production, distribution, sales, and use in the consumer) [20]. All of this should be included in the life cycle analysis and be translated into additional environmental burdens. Moreover, there is a whole range of food products requiring energy in the process of preparation for consumption (washing, cooking, roasting). Examples include raw meat, pasta, coffee beans, bread mix, potatoes, etc. These are all passive products, for which preparation instructions included on the packaging by the manufacturer necessitate indirect energy consumption (boiling water in the kettle, energy consumption by the oven, energy consumption by the dishwasher, etc.), without which their basic function could not be realised.

The energy intensity criterion over the food life cycle is also important given current market trends and the search for alternatives to conventional food. Research results obtained by Smetana et al. [21] are an interesting example as they show that the potential energy intensity of the laboratory meat production phase is so high that, when converted to a functional unit $(1 \mathrm{~kg}$ ready for meat consumption or the supply of $3.75 \mathrm{MJ}$ of energy from food), it fares much worse from the perspective of the whole life cycle than other products (chicken, dairy-based, gluten-based, insect-based, soymeal-based, and mycoproteins-based) [21]. This is a good illustration of the eco-design principle. When seeking alternative solutions, the environmental impacts should not be shifted from one phase to another. In this example, the issue of the negative cradle (farm) impact was addressed, but a significant increase in energy intensity has occurred at a different stage.

Another example of a passive product category with a significant contribution to the indirect power consumption life cycle is clothing. In this case, standard use conditions provide for regular washing. As indicated in [22], at present, washing machines are 
prevailingly used across most continents. While the use of raw materials and clothing production remains an important source of negative impacts during the life cycles of the garment, the electricity consumption of the washing machine during the use phase is a significant source of environmental impact.

From the point of view of energy modelling in the LCA study, two inter-related issues are important:

- operational control over the energy generation process-energy can be generated on-site by the LCA commissioner (he/she has control and supervision of the process) or provided through the grid from the supplier (lack of supervision and operational control);

- access to specific data-if the energy is generated on-site, the analyst has access to the primary data and this process falls under the so-called foreground system. However, if the energy is supplied by a supplier, the LCA commissioner may or may not have access to specific data. In the latter case, energy generation falls within the scope of the so-called background system and is modelled using secondary data.

What is also related is the life cycle phase where energy consumption occurs. Depending on the type of test, there may be detailed guidelines on how to model energy consumption at the different life cycle stages. For example, life-cycle-based analysis conducted for Environmental Product Declaration (EPD) [5] or for calculating the Environmental Footprint of Products (PEF) [6,23] should model the energy in accordance with the detailed guidelines included in the relevant product category rules.

From the point of view of assessing the quality of data, the LCA analyst should, to the greatest possible extent, use data reflecting the geographical location of the process (life cycle stage), its technology, and time. From an energy perspective, this means that either the primary data (if available) is used or secondary datasets representative of the country in which the life cycle stage is performed are used. In the absence of such data, datasets for the region may possibly be used, but this results in reduced data quality and adds uncertainty to the final results. It is important to properly model the energy to be consumed during the use of products that are sold and operated in different countries. This applies not only to competing products from different manufacturers but also to the structure of sales and export within a single company. The differences between energypowered products are potentially significant, as demonstrated by the LCA comparison of the annual environmental impacts of an average vacuum cleaner in 2020 used in various EU countries conducted by Gallego-Schmid et al. [4]. From this perspective, the only solution to improve the result for such products seems to lie in the gradual improvement of the national energy mixes for individual countries.

\section{Materials and Methods}

In this paper, we present the results of the life cycle assessment of a hypothetical refrigerator, assuming different geographical locations for specific life cycle stages and various options for modelling electricity. According to the ISO standards [24], life cycle assessment (LCA) consists of four phases: goal and scope definition, inventory analysis, impact assessment, and interpretation. In the first phase, the intended use, reasons for carrying out the study, the functional unit, the reference flow, system boundaries, allocation procedures, and other aspects need to be defined. The inventory analysis involves data gathering and calculation procedures to quantify the flows (inputs and outputs) of a product system. Two main sorts of flows exist: elementary flows and non-elementary flows. The first category includes all the inputs and outputs to be exchanged with the environment without previous (inputs) or subsequent (outputs) human transformation. Non-elementary flows relate to material and energy flows to be transformed by humans and exchanged with the technosphere. The impact assessment phase is aimed at assessing the significance of the potential environmental impacts. The results are related to various environmental issues named 'environmental impact categories' and category indicators. Depending on the LCIA method, it is possible to express the environmental impact in the form of a cumulated 
score, which is a single number reflecting the potential environmental impact for all impact categories together. The interpretation phase is focused on providing findings from the inventory and impact assessment steps. Conclusions and recommendations need to be consistent with the goal and scope of the study [24]. In our case study, the ReCiPe (H/A) endpoint impact assessment method [25] was used. The impact assessment results will be presented in the form of a single score. The Ecoinvent 3.6 database [26] was used together with SimaPro 9.1 software.

The goal of the study is to assess the potential environmental impact of the life cycle of a refrigerator and to identify the elements with the greatest environmental contribution. The life cycle is to be modelled in different scenarios related to various locations of suppliers and electricity mixes. The functional unit is defined as the supply of $230 \mathrm{~L}$ of cooling space $\left(4{ }^{\circ} \mathrm{C}\right)$ and $110 \mathrm{~L}$ of refrigeration space $\left(-18^{\circ} \mathrm{C}\right)$ for food storage for 10 years of refrigerator use. One piece of equipment weighing $58.4 \mathrm{~kg}$, in the energy efficiency class $\mathrm{F}$, was used as a reference flow. The refrigerator was assumed to have been produced in 2020. The refrigerator's life cycle was divided into eight stages (Table 1). A more detailed description of the stages can be found in the Supplementary Information.

Table 1. Inventory data for the life cycle of the analyzed refrigerator (1 piece).

\begin{tabular}{|c|c|c|c|c|c|c|}
\hline \multirow{2}{*}{ 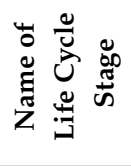 } & \multirow[b]{2}{*}{$\begin{array}{l}\text { Symbol of Life } \\
\text { Cycle Stage }\end{array}$} & \multicolumn{5}{|c|}{ Inventory Results } \\
\hline & & $\begin{array}{c}\text { Flow Type } \\
\text { and Process Location * }\end{array}$ & Flow Name & $\begin{array}{l}\text { Amount } \\
\text { (Virtual) }\end{array}$ & Unit & $\begin{array}{c}\text { Electricity Source/Mix Used to } \\
\text { Model Electricity } \\
\text { Consumption in Each Process }\end{array}$ \\
\hline \multirow{18}{*}{ 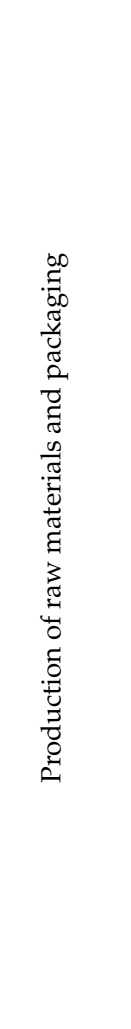 } & \multirow{18}{*}{ PRMP } & $\begin{array}{l}\text { Input from } \\
\text { technosphere } \\
\text { (AT) }\end{array}$ & Phenyl isocyanate & 6.479 & $\mathrm{~kg}$ & Photovoltaic electricity \\
\hline & & $\begin{array}{l}\text { Input from } \\
\text { technosphere } \\
\text { (DE) }\end{array}$ & Aluminium, primary, ingot & 2.189 & $\mathrm{~kg}$ & $\begin{array}{c}\text { Residual electricity mix DE, } 2020 \\
\text { or } \\
\text { Hydro, DE }\end{array}$ \\
\hline & & $\begin{array}{l}\text { Input from } \\
\text { technosphere } \\
\text { (PL) }\end{array}$ & Copper & 1.308 & $\mathrm{~kg}$ & $\begin{array}{c}\text { Residual electricity mix PL, } 2020 \\
\text { or } \\
\text { Photovoltaic }\end{array}$ \\
\hline & & $\begin{array}{l}\text { Input from } \\
\text { technosphere } \\
\text { (PL) }\end{array}$ & Steel, low-alloyed & 32.093 & $\mathrm{~kg}$ & $\begin{array}{c}\text { Residual electricity mix PL, } 2020 \\
\text { or } \\
\text { Wind, PL }\end{array}$ \\
\hline & & & $\begin{array}{l}\text { 1,1-difluoroethane, } \\
\text { HFC-152a }\end{array}$ & 0.239 & $\mathrm{~kg}$ & \multirow{14}{*}{$\begin{array}{l}\text { Average electricity mix } \\
\text { representative of Europe }\end{array}$} \\
\hline & & & Dimethyldichlorosilane & 0.003 & $\mathrm{~kg}$ & \\
\hline & & & Epoxy resin, liquid & 0.111 & $\mathrm{~kg}$ & \\
\hline & & & Lithium fluoride & 0.003 & $\mathrm{~kg}$ & \\
\hline & & & Methylcyclopentane & 0.479 & $\mathrm{~kg}$ & \\
\hline & & & Polyol & 4.799 & $\mathrm{~kg}$ & \\
\hline & & Inputs from & $\begin{array}{l}\text { Polyvinylchloride, } \\
\text { suspension polymerised }\end{array}$ & 0.466 & $\mathrm{~kg}$ & \\
\hline & & $\begin{array}{l}\text { technosphere } \\
\text { (EUR) }\end{array}$ & $\begin{array}{l}\text { Sodium hydroxide, without } \\
\text { water, in } 50 \% \text { solution state }\end{array}$ & 0.001 & $\mathrm{~kg}$ & \\
\hline & & & $\begin{array}{c}\text { Sodium percarbonate, } \\
\text { powder }\end{array}$ & 0.003 & $\mathrm{~kg}$ & \\
\hline & & & Sodium silicate, solid & 0.004 & $\mathrm{~kg}$ & \\
\hline & & & $\begin{array}{l}\text { Polyethylene, linear low } \\
\text { density, granulate }\end{array}$ & 0.297 & $\mathrm{~kg}$ & \\
\hline & & & Plastic extrusion & 0.297 & $\mathrm{~kg}$ & \\
\hline & & & EUR-wooden pallet & 25.000 & $\mathrm{~kg}$ & \\
\hline & & & Polystyrene, high impact & 10.222 & $\mathrm{~kg}$ & \\
\hline
\end{tabular}


Table 1. Cont.

\begin{tabular}{|c|c|c|c|c|c|c|}
\hline \multirow{2}{*}{ 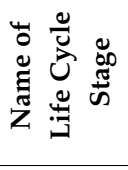 } & \multirow[b]{2}{*}{$\begin{array}{l}\text { Symbol of Life } \\
\text { Cycle Stage }\end{array}$} & \multicolumn{5}{|c|}{ Inventory Results } \\
\hline & & $\begin{array}{c}\text { Flow Type } \\
\text { and Process Location* }\end{array}$ & Flow Name & $\begin{array}{l}\text { Amount } \\
\text { (Virtual) }\end{array}$ & Unit & $\begin{array}{l}\text { Electricity Source/Mix Used to } \\
\text { Model Electricity } \\
\text { Consumption in Each Process }\end{array}$ \\
\hline \multirow{4}{*}{ 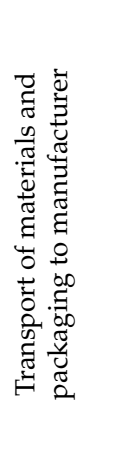 } & \multirow{4}{*}{ TRANS } & $\begin{array}{l}\text { Input from } \\
\text { technosphere } \\
(\mathrm{PL} \rightarrow \mathrm{PL} \\
250 \mathrm{~km})^{*}\end{array}$ & $\begin{array}{l}\text { Transport, freight lorry, } \\
\text { 16-32t, EURO4 }\end{array}$ & 0.835 & $\mathrm{tkm}$ & \\
\hline & & $\begin{array}{c}\text { Input from } \\
\text { technosphere } \\
(\mathrm{DE} \rightarrow \mathrm{PL}, 570 \mathrm{~km}) *\end{array}$ & $\begin{array}{l}\text { Transport, freight lorry, } \\
\text { 16-32t, EURO4 }\end{array}$ & 1.248 & $\mathrm{tkm}$ & \\
\hline & & $\begin{array}{c}\text { Input from } \\
\text { technosphere } \\
(\mathrm{AT} \rightarrow \mathrm{PL}, 670 \mathrm{~km})\end{array}$ & $\begin{array}{l}\text { Transport, freight lorry, } \\
\text { 16-32t, EURO4 }\end{array}$ & 4.342 & $\mathrm{tkm}$ & \\
\hline & & $\begin{array}{l}\text { Input from } \\
\text { technosphere } \\
(\text { EUR } \rightarrow \text { PL, } \\
1000 \mathrm{~km})^{*}\end{array}$ & $\begin{array}{l}\text { Transport, freight lorry, } \\
\text { 16-32t, EURO4 }\end{array}$ & 41.633 & $\mathrm{tkm}$ & \\
\hline \multirow{7}{*}{ 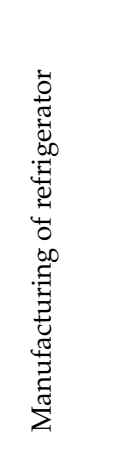 } & \multirow{7}{*}{ MAN } & \multirow{6}{*}{$\begin{array}{l}\text { Inputs from } \\
\text { technosphere } \\
\text { (PL) }\end{array}$} & $\begin{array}{l}\text { Compressed air, } \\
800 \text { kPa gauge }\end{array}$ & 19.018 & $\mathrm{~m}^{3}$ & Residual electricity mix PL, 2020 \\
\hline & & & Metal-working factory & $2.75 \times 10^{-8}$ & $\mathrm{P}$ & \\
\hline & & & $\begin{array}{l}\text { Energy and auxiliary inputs, } \\
\text { metal-working factory }\end{array}$ & $2.75 \times 10^{-8}$ & $\mathrm{~kg}$ & $\begin{array}{c}\text { Residual electricity mix PL, } 2020 \\
\text { or } \\
\text { Photovoltaic }\end{array}$ \\
\hline & & & Electricity, high voltage & 10.948 & $\mathrm{kWh}$ & \\
\hline & & & Heat, natural gas & 10.53 & MJ & Residual electricity mix PL, 2020 \\
\hline & & & $\begin{array}{l}\text { Steam, in the chemical } \\
\text { industry }\end{array}$ & 7.777 & $\mathrm{~kg}$ & Residual electricity mix PL, 2020 \\
\hline & & $\begin{array}{l}\text { Emission to air } \\
\text { (PL) }\end{array}$ & $\begin{array}{c}\text { Ethane, 1,1-difluoro-, } \\
\text { HFC-152a }\end{array}$ & 0.0239 & $\mathrm{~kg}$ & \\
\hline \multirow{4}{*}{ 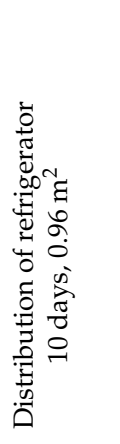 } & \multirow{4}{*}{ DISTR } & $\begin{array}{l}\text { Output to technosphere } \\
\qquad(\mathrm{PL})\end{array}$ & Wastewater, average & 0.055 & $\mathrm{~m}^{3}$ & Residual electricity mix PL, 2020 \\
\hline & & $\begin{array}{l}\text { Input from } \\
\text { technosphere } \\
\text { (PL) }\end{array}$ & Electricity, low voltage & 0.789 & $\mathrm{kWh}$ & Supplier electricity mix PL, 2020 \\
\hline & & $\begin{array}{l}\text { Input from } \\
\text { technosphere } \\
(\mathrm{PL})\end{array}$ & Heat & 9.468 & MJ & Supplier electricity mix PL, 2020 \\
\hline & & $\begin{array}{l}\text { Input from } \\
\text { technosphere } \\
\text { (PL and/or DE) }\end{array}$ & $\begin{array}{l}\text { Transport, freight lorry, } \\
\text { 16-32t, EURO4 }\end{array}$ & $\begin{array}{l}42.65 \\
\text { or } \\
63.98 \\
\text { or } \\
85.3\end{array}$ & tkm & $\begin{array}{c}42.65 \mathrm{tkm}-100 \% \text { of products } \\
\text { destined for the Polish market } \\
63.98 \mathrm{tkm}-50 \% / 50 \% \text { Polish and } \\
\text { German markets } \\
85.3 \mathrm{tkm}-100 \% \text { German market }\end{array}$ \\
\hline 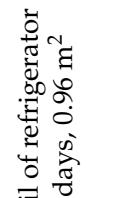 & RETA & $\begin{array}{l}\text { Input from } \\
\text { technosphere } \\
\text { (PL and/or DE) }\end{array}$ & Electricity & 31.956 & $\mathrm{kWh}$ & $\begin{array}{l}\text { Supplier electricity mix PL, } 2020 \\
\text { and/or } \\
\text { Supplier electricity mix DE, } 2020\end{array}$ \\
\hline \multirow{5}{*}{ 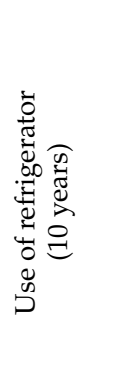 } & \multirow{5}{*}{ USE } & Inputs from & Electricity & 3030 & $\mathrm{kWh}$ & $\begin{array}{l}\text { Supplier electricity mix PL, } 2020 \\
\quad \text { and/or } \\
\text { Supplier electricity mix DE, } 2020\end{array}$ \\
\hline & & $\begin{array}{l}\text { technosphere } \\
\text { (PL and/or DE) }\end{array}$ & $\begin{array}{l}\text { Tap water } \\
\text { Soap }\end{array}$ & $\begin{array}{l}100 \\
0.02\end{array}$ & $\begin{array}{l}\mathrm{kg} \\
\mathrm{kg}\end{array}$ & $\begin{array}{l}\text { Average electricity mix } \\
\text { representative of Europe }\end{array}$ \\
\hline & & & $\begin{array}{l}\text { 1,1-difluoroethane, } \\
\text { HFC-152a }\end{array}$ & 0.0239 & $\mathrm{~kg}$ & \\
\hline & & $\begin{array}{l}\text { Emission to air } \\
\text { (PL and/or DE) }\end{array}$ & $\begin{array}{c}\text { Ethane, 1,1-difluoro-, } \\
\text { HFC-152a }\end{array}$ & 0.0239 & $\mathrm{~kg}$ & \\
\hline & & $\begin{array}{l}\text { Output to technosphere } \\
\text { (PL and/or DE) }\end{array}$ & Wastewater, average & 100.2 & $\mathrm{dm}^{3}$ & $\begin{array}{l}\text { Average electricity mix } \\
\text { representative of Europe }\end{array}$ \\
\hline
\end{tabular}


Table 1. Cont.

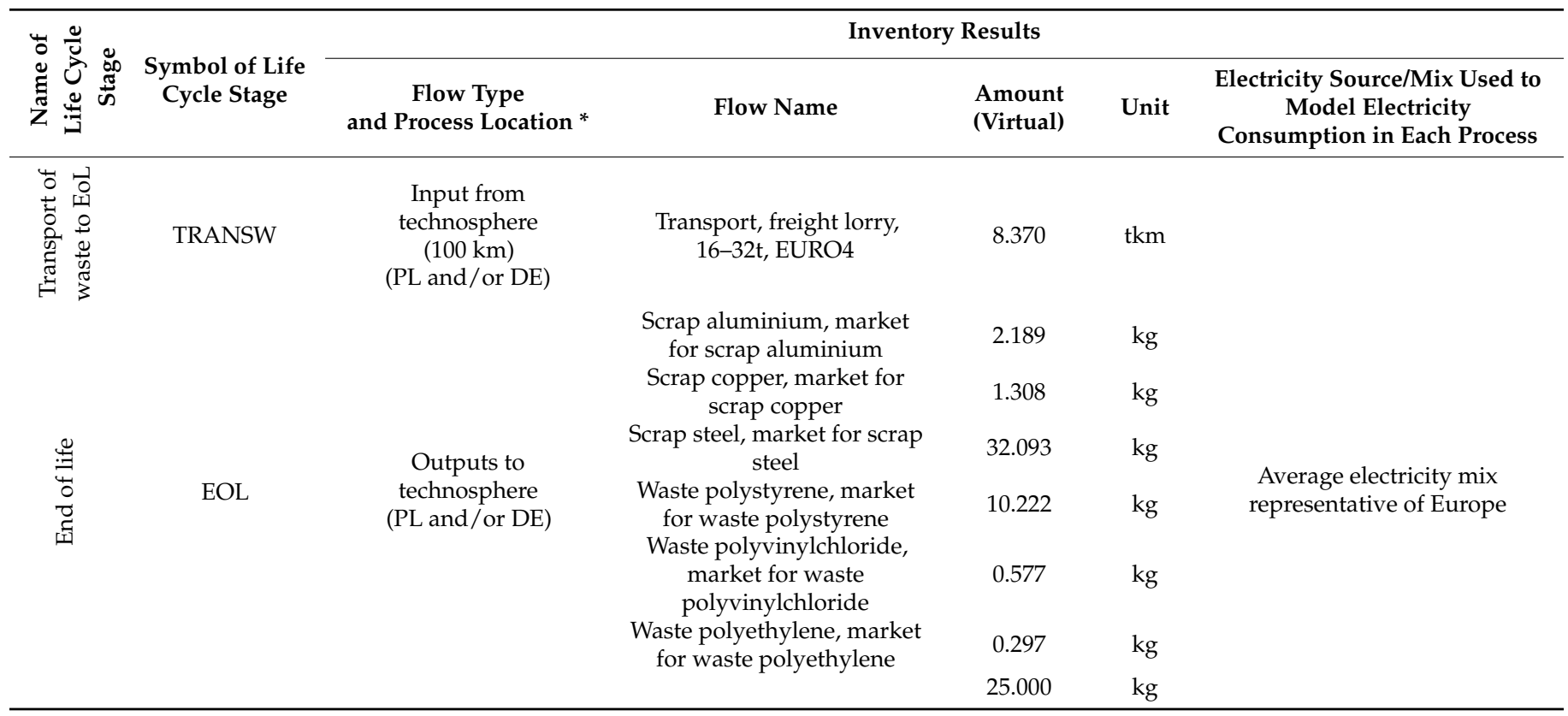

${ }^{*}$ for Poland and Europe virtual distances are used, for Austria and Germany the distance between the capitals is used.

The total weight of the product is $58.4 \mathrm{~kg}$ and its packaging weighs $25.3 \mathrm{~kg}$. These are composed of 17 materials (Table 1). The production of these materials involves direct energy consumption (electricity and/or heat) in the production process itself and indirect consumption resulting from the activities of subcontractors. There are four main materials constituting $72 \%$ of the weight of the refrigerator: low-alloyed steel (32.093 kg per refrigerator), phenyl isocyanate $(6.479 \mathrm{~kg}$ per refrigerator), primary aluminium ingot $(2.189 \mathrm{~kg}$ per refrigerator), and copper (1.308 kg per refrigerator). According to the Ecoinvent database used, the direct consumption of electricity in the production process for the four listed materials is as follows (to present a difference in electricity consumption, the low-alloyed steel has been divided into converter and electric ones): $0.333 \mathrm{kWh} / \mathrm{kg}$ of phenyl isocyanate; $0.095 \mathrm{kWh} / \mathrm{kg}$ of aluminium, primary, ingot; $0.547 \mathrm{kWh} / \mathrm{kg}$ of copper; $0.0219 \mathrm{kWh} / \mathrm{kg}$ of converter low-alloyed steel; and $0.4236 \mathrm{kWh} / \mathrm{kg}$ of electric low-alloyed steel. Let us assume that the aluminium supplier runs its business in Germany (DE), steel and copper suppliers in Poland (PL), and the supplier of phenyl isocyanate operates in Austria (AT).

Besides the consumption of electricity during production of the aluminium ingot, much more energy-intensive is another process (upstream) - the production of primary liquid aluminium. The Hall-Héroult process with electrolytic cells—pre-baked or Söderberg's-is used in European smelters [27]. The pre-bake technology is clearly dominant, as $95 \%$ of the primary aluminium in Europe was produced with this technology in 2015 [28]. In Germany, four main aluminium companies operate and the five primary aluminium smelters mainly use technology based on prebaked electrolytic cells [27]. According to the Ecoinvent datasets, the use of electricity during the production of primary liquid aluminium using prebaked electrolytic cells is $14.854 \mathrm{kWh} / \mathrm{kg}$ of liquid aluminium, while the Söderberg process uses $16.951 \mathrm{kWh} / \mathrm{kg}$ of aluminium. In total, the electricity consumption during the most energy-intensive processes in the life cycle of aluminium equalled $32.981 \mathrm{kWh}$ per refrigerator. According to the European Aluminium Association, in 2010, 54\% of the electricity used in the European Aluminium Industry came from hydropower produced in Norway and Iceland [29]. In the same year, the electricity used in the aluminium industry and generated in Germany came mainly from non-renewable sources: coal, nuclear, and oil [29]. According to more recent Ecoinvent datasets, the share of renewable energy (hydro) in the electricity mix used by the aluminium industry (EU27+EFTA) is more than 
$70 \%$, but only about $1 \%$ of the renewable electricity comes from Germany. In this country, non-renewable sources are still dominant: coal, nuclear, natural gas, and oil [26].

In terms of mass, the most relevant construction material of the presented refrigerator is the low-alloyed steel. In our case study, it was assumed that the steel is produced in Poland. On the world scale, Poland has been ranked in 19th position among major steelproducing countries with a crude steel production equalling 9 million tonnes in 2019 [30]. In the same year, in Poland, 4.4 million tonnes of pig iron was produced, which ranked this country in 10th position in the European Union [30]. A total of 0.2 million tonnes of pig iron was imported, mainly from European countries [30]. In recent years, two technologies of crude steel production have dominated in the Polish steel industry: the blast furnace-basic oxygen furnace (BOF) and the electric process, with shares of $54.9 \%$ and $45.1 \%$, respectively [30,31]. According to the Ecoinvent database, the direct use of electricity during the converter production of low-alloyed steel is $0.0219 \mathrm{kWh} / \mathrm{kg}$, while, with the electric process, it is equal to $0.42361 \mathrm{kWh} / \mathrm{kg}$. In the integrated process, the main input is pig iron. The consumption of electricity during pig iron production is relatively low, as this process is much more dependent on thermal energy. In total, the electricity consumption during the most relevant processes in the life cycle of steel equalled $6.53 \mathrm{kWh}$ per refrigerator.

In our analysis, we will model the production of the four mentioned materials in two scenarios. First, we assume that the suppliers use untracked electricity (no Energy Attribute Certificates e.g., Guarantees of Origin used) [32]. Then, in the second scenario, we assume that they consume renewable tracked electricity during their production processes. In the first case, we will use national specific residual mixes modelled according to the share of energy carriers listed for 2020 by the Association of Issuing Bodies (AIB) for individual countries [33]. The residual electricity mixes for Germany and Poland differ significantly. In the German mix, a much higher share of nuclear and gas electricity is visible, while, in the Polish case, electricity from coal has the dominant share. In the second case, we will assume that the aluminium supplier has a guarantee of origin for hydro electricity, the copper supplier for photovoltaic electricity and the steel supplier for wind electricity (Table 1). Austria is an exceptional case here. According to AIB's statistics, $100 \%$ of electricity was tracked in Austria in 2020 [33], which means that there is no residual mix for that country (it is zero). This also means that a supplier operating in Austria must use electricity covered by the tracking system and contractual instruments. For this reason, in our analysis, the process of generating the energy used to produce phenyl isocyanate will be modelled only as photovoltaic electricity. In any case, country-specific datasets for energy generation (AT, DE, PL) will be used. Consumption of other materials during energy generation will be modelled using averaged energy mixes representative of Europe.

In our example, the criteria for differentiating electrical power over the life cycle of the refrigerator analysed included the power plant location (country) and the justification (having its own renewable energy installation or contractual instruments such as a guarantee of origin for the energy purchased from the supplier) for modelling renewable energy. Self-modelled (using LCA software) datasets for electricity production in Poland and Germany were used in the analysis. Calculations for energy imports and the shares of individual technologies were based on the electricity production datasets available in the Ecoinvent database 3.6. The shares of individual energy carriers and technologies were selected in such a manner as to be consistent with the residual mix and supplier mix published by AIB for 2020 (Table 2). The shares of individual carriers in energy mixes according to the AIB report are presented below, while Table 3 presents the calculated environmental impacts for the generation of $1 \mathrm{kWh}$ of electricity according to the datasets created on their basis. As can be seen, the supplier mixes for Poland and Germany differ significantly. The German mix has a high share of renewable energy. Moreover, 58.11\% of the energy is covered by a tracking system (e.g., guarantees of origin). The remaining untracked energy makes up the residual mix, in which $42.82 \%$ is hard coal. For Poland, we can only see a small percentage of energy covered by the tracking system (only $5.65 \%$ ) and 
a significantly higher share of energy from fossil fuels. In Poland, due to the small share of tracked energy, not much difference between the supplier mix and the residual mix was observed. However, it is worth noting at this point that in 2020 the mix for Poland was clearly better than in the previous years, and, in 2020, for the first time the share of energy from hard coal dropped below $70 \%$.

Table 2. Electricity residual mix and supplier mix for Poland and Germany in 2020 according to the Association of Issuing Bodies (AIB) [33].

\begin{tabular}{|c|c|c|c|c|}
\hline & \multicolumn{2}{|c|}{ Germany (DE) } & \multicolumn{2}{|c|}{ Poland (PL) } \\
\hline & Supplier Mix 2020 & Residual Mix 2020 & Supplier Mix 2020 & Residual Mix 2020 \\
\hline $\begin{array}{l}\text { Energy from unspecified } \\
\text { renewable carriers }\end{array}$ & $0.52 \%$ & $0.00 \%$ & $0.00 \%$ & $0.00 \%$ \\
\hline Energy from biomass & $3.90 \%$ & $0.00 \%$ & $3.24 \%$ & $2.60 \%$ \\
\hline Solar energy & $9.79 \%$ & $0.89 \%$ & $1.48 \%$ & $1.50 \%$ \\
\hline Geothermal energy & $0.24 \%$ & $0.00 \%$ & $0.00 \%$ & $0.00 \%$ \\
\hline Energy from wind & $29.59 \%$ & $0.04 \%$ & $6.92 \%$ & $2.92 \%$ \\
\hline Hydro energy & $24.97 \%$ & $0.00 \%$ & $1.44 \%$ & $0.98 \%$ \\
\hline Nuclear energy & $6.64 \%$ & $21.23 \%$ & $3.78 \%$ & $4.01 \%$ \\
\hline Energy from unspecified fossil carriers & $1.73 \%$ & $5.53 \%$ & $2.50 \%$ & $2.52 \%$ \\
\hline Energy from hard coal & $13.4 \%$ & $42.82 \%$ & $66.53 \%$ & $70.51 \%$ \\
\hline Energy from lignite & $0.00 \%$ & $0.00 \%$ & $0.15 \%$ & $0.16 \%$ \\
\hline Energy from oil & $0.43 \%$ & $1.36 \%$ & $0.12 \%$ & $0.12 \%$ \\
\hline Energy from gas & $8.80 \%$ & $28.14 \%$ & $13.84 \%$ & $14.67 \%$ \\
\hline Untracked energy & $41.89 \%$ & $100.00 \%$ & $94.35 \%$ & $100.00 \%$ \\
\hline Tracked energy & $58.11 \%$ & $0.00 \%$ & $5.65 \%$ & $0.00 \%$ \\
\hline
\end{tabular}

Table 3. Environmental impact of the production of $1 \mathrm{kWh}$ of electricity, calculated for residual and supplier mixes modelled in accordance with data presented in Table 2.

\begin{tabular}{|c|c|c|c|c|c|c|}
\hline \multirow[b]{2}{*}{$\begin{array}{l}\text { Life-Cycle Impact } \\
\text { Assessment Method }\end{array}$} & \multirow[b]{2}{*}{ Impact Category } & \multirow[b]{2}{*}{ Unit } & \multicolumn{2}{|c|}{ Germany (DE) } & \multicolumn{2}{|c|}{ Poland (PL) } \\
\hline & & & $\begin{array}{l}\text { Supplier } \\
\text { Mix } 2020\end{array}$ & $\begin{array}{l}\text { Residual } \\
\text { Mix } 2020\end{array}$ & $\begin{array}{l}\text { Supplier } \\
\text { Mix } 2020\end{array}$ & $\begin{array}{l}\text { Residual } \\
\text { Mix } 2020\end{array}$ \\
\hline IPCC 2013, 100a & Global warming & $\mathrm{kg} \mathrm{CO}_{2}$ eq. & 0.298 & 0.689 & 0.938 & 0.988 \\
\hline ReCiPe 2016, midpoint & Global warming & $\mathrm{kg} \mathrm{CO}_{2}$ eq. & 0.302 & 0.699 & 0.952 & 1.003 \\
\hline EF 2.0 method, adapted & Climate change & $\mathrm{kg} \mathrm{CO}_{2}$ eq. & 0.303 & 0.700 & 0.954 & 1.006 \\
\hline ReCiPe 2016, endpoint & Single score & $\mathrm{Pt}$ & 0.008 & 0.018 & 0.036 & 0.038 \\
\hline
\end{tabular}

The differences in the mixes for each country translate into the life cycle environmental impacts associated with the generation of $1 \mathrm{kWh}$ of electricity. Although only the weighted results of environmental indicators will be presented in the next chapter, due to the importance of climate change, Table 3 additionally presents the characterized results illustrating the greenhouse gas emissions $\left(\mathrm{kg} \mathrm{CO}_{2} \mathrm{eq}\right)$ over the energy life cycle calculated using three methods: IPCC 2013, ReCiPe 2016 midpoint [25], and EF 2.0 adapted method [23]. A single score calculated using the ReCiPe 2016 endpoint [25] was also reported. The differences between the mixes are very distinct and will be crucial for the environmental impact results throughout the life cycle of the refrigerator analyzed.

The analyses were performed under the different scenarios described and are presented in the Supplementary Information in Table S1. 


\section{Results}

The environmental impact was calculated using the ReCiPe Endpoint 2016 (H) v.1.04/World (2010) H/A method [25]. It provides information about the environmental impact of a product in the individual impact categories or in the form of a single indicator (single score). The higher the positive indicator score, the more negative the environmental impact. In our paper, we will present the weighted results in the form of a single score expressed in Pt. Figures 1-5 show the environmental impact of the different modelling options in the selected life cycle stages of the refrigerator, while Figure 6 and Table 4 show the results for the whole life cycle of the refrigerator. More detailed results can be found in the Supplementary Information (Tables S2-S9).

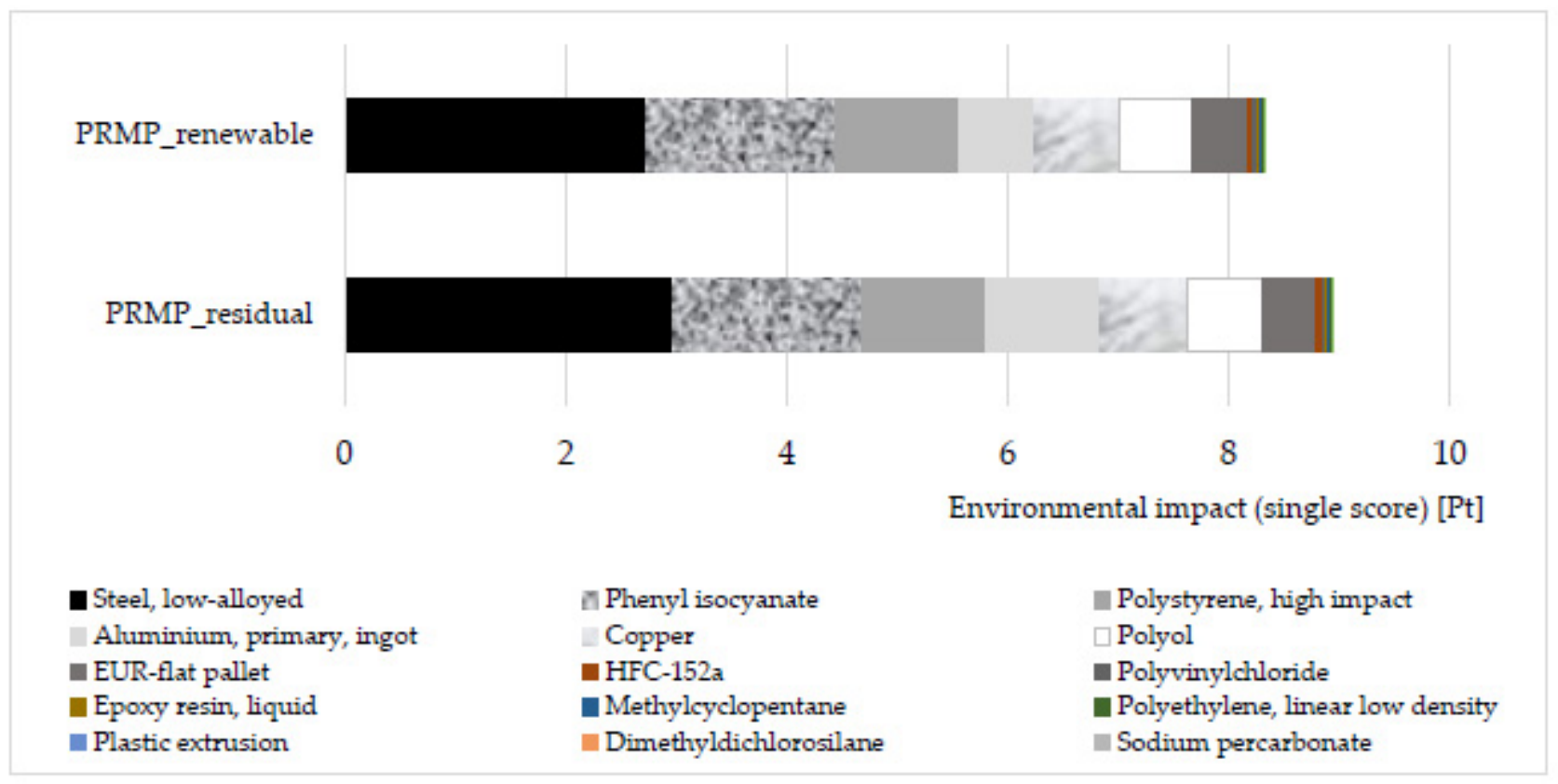

Figure 1. Environmental impact of the life cycle stage Production of raw materials and packaging (PRMP) per 1 refrigerator $(8.952 \mathrm{Pt}=$ residual, $8.329 \mathrm{Pt}=$ renewable, decrease by $7 \%)$.

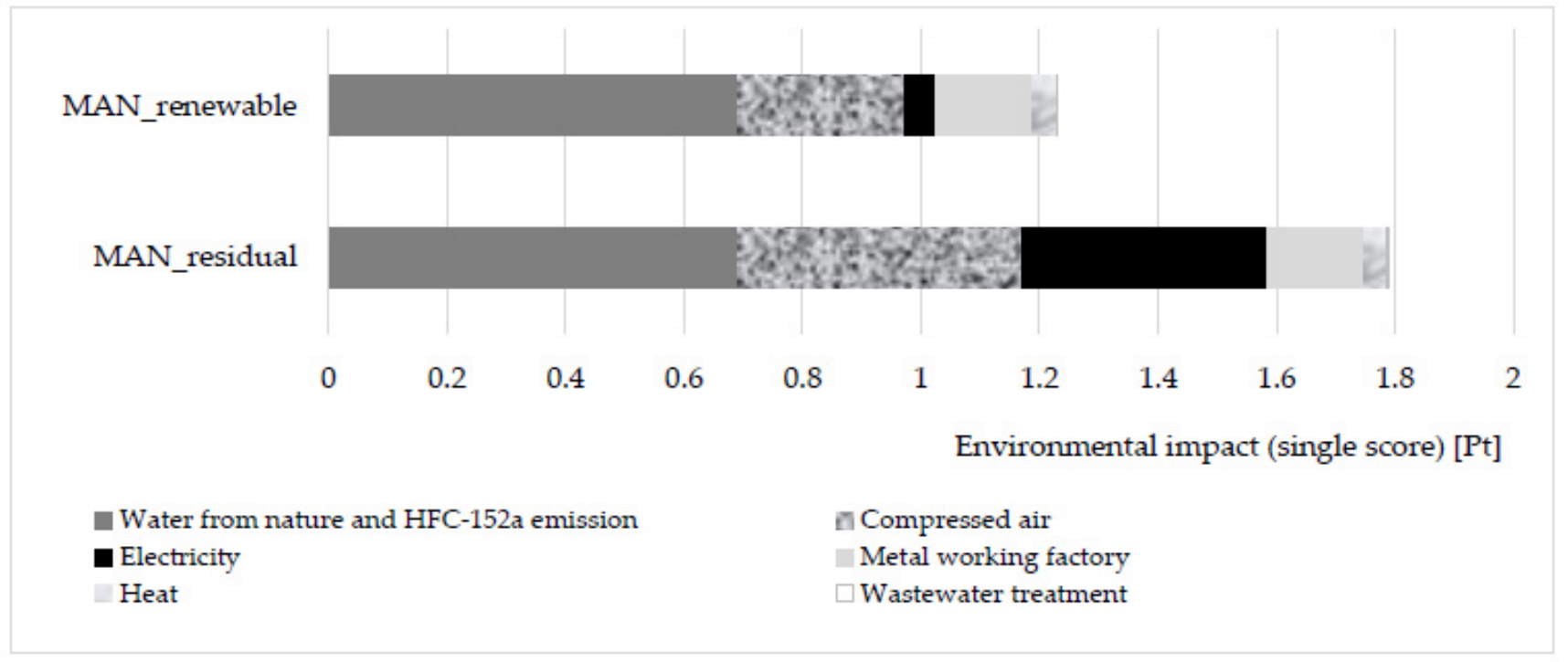

Figure 2. Environmental impact of the life cycle stage Manufacturing of refrigerator (MAN) per 1 refrigerator $(1.788 \mathrm{Pt}=\mathrm{residual}$, $1.230 \mathrm{Pt}=$ renewable, decrease by $31 \%)$. 


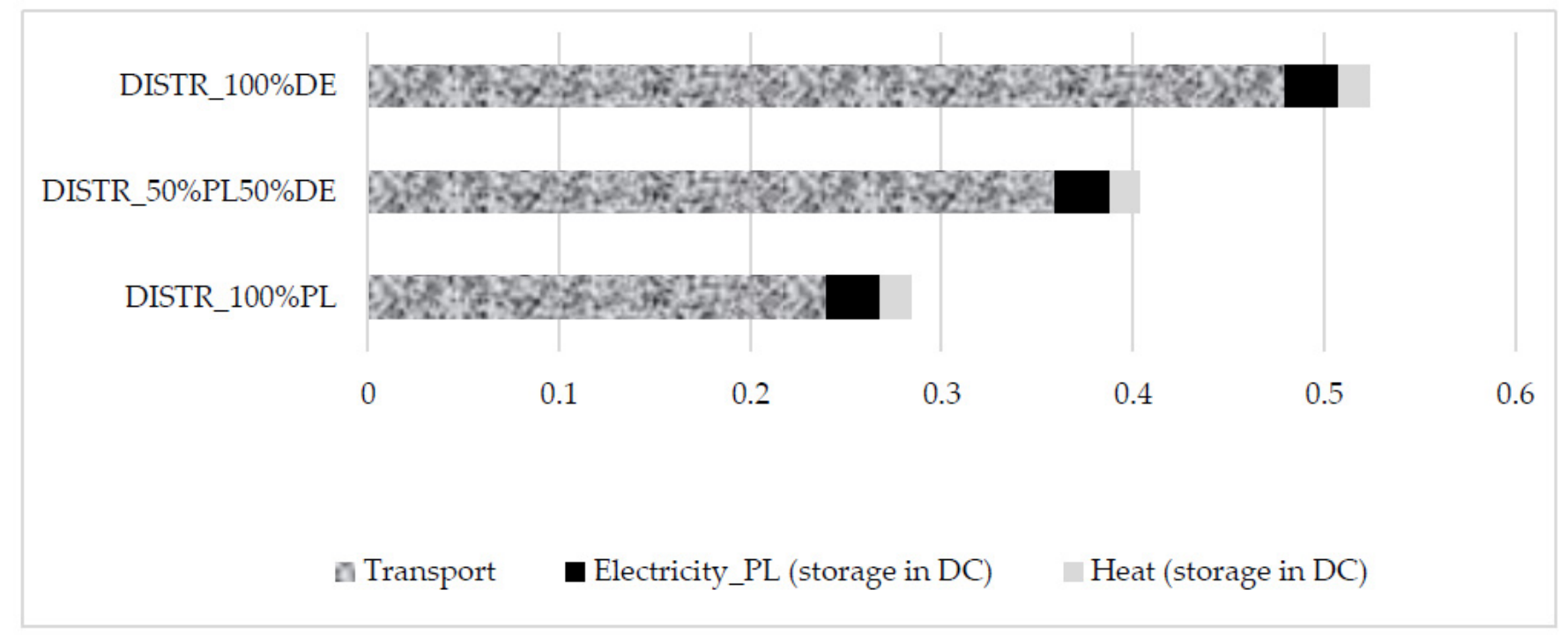

Figure 3. Environmental impact of the life cycle stage Distribution (DISTR) per 1 refrigerator $(0.523 \mathrm{Pt}=100 \% \mathrm{DE}$, $0.404 \mathrm{Pt}=50 \% \mathrm{PL} 50 \% \mathrm{DE}, 0.284 \mathrm{Pt}=100 \% \mathrm{PL}$, decrease by $46 \%$ ).

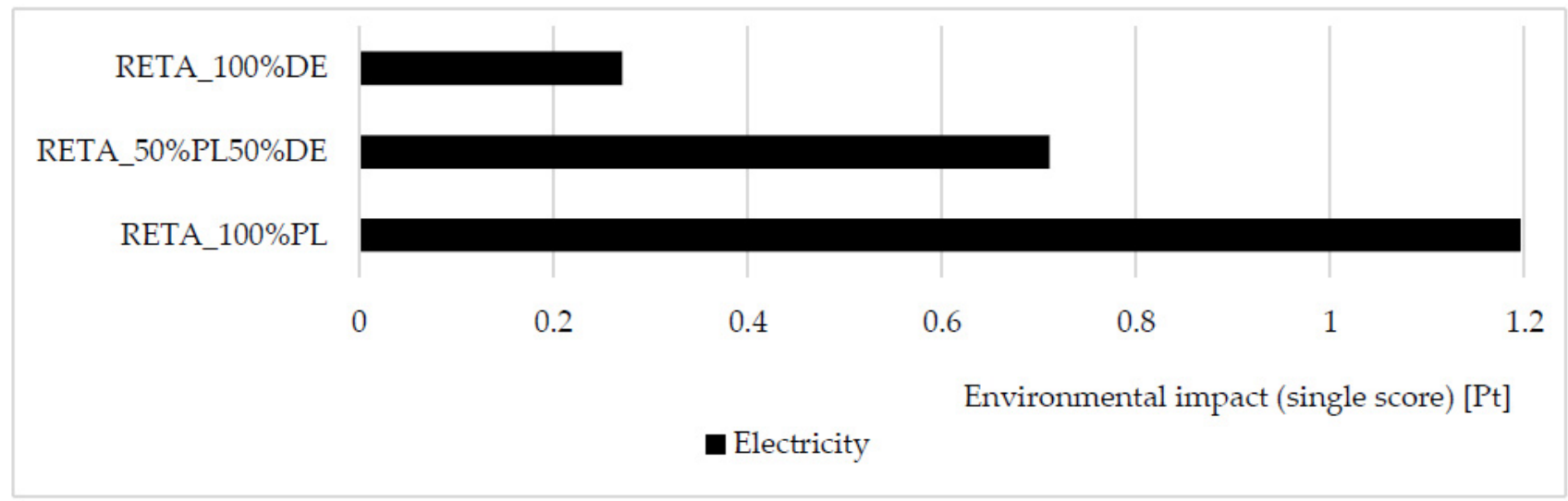

Figure 4. Environmental impact of the life cycle stage Retail (RETA) per 1 refrigerator $(0.271 \mathrm{Pt}=100 \% \mathrm{DE}, 0.711 \mathrm{Pt}=50 \% \mathrm{PL} 50 \% \mathrm{DE}$, $1.196 \mathrm{Pt}=100 \% \mathrm{PL}$, decrease by $77 \%)$.

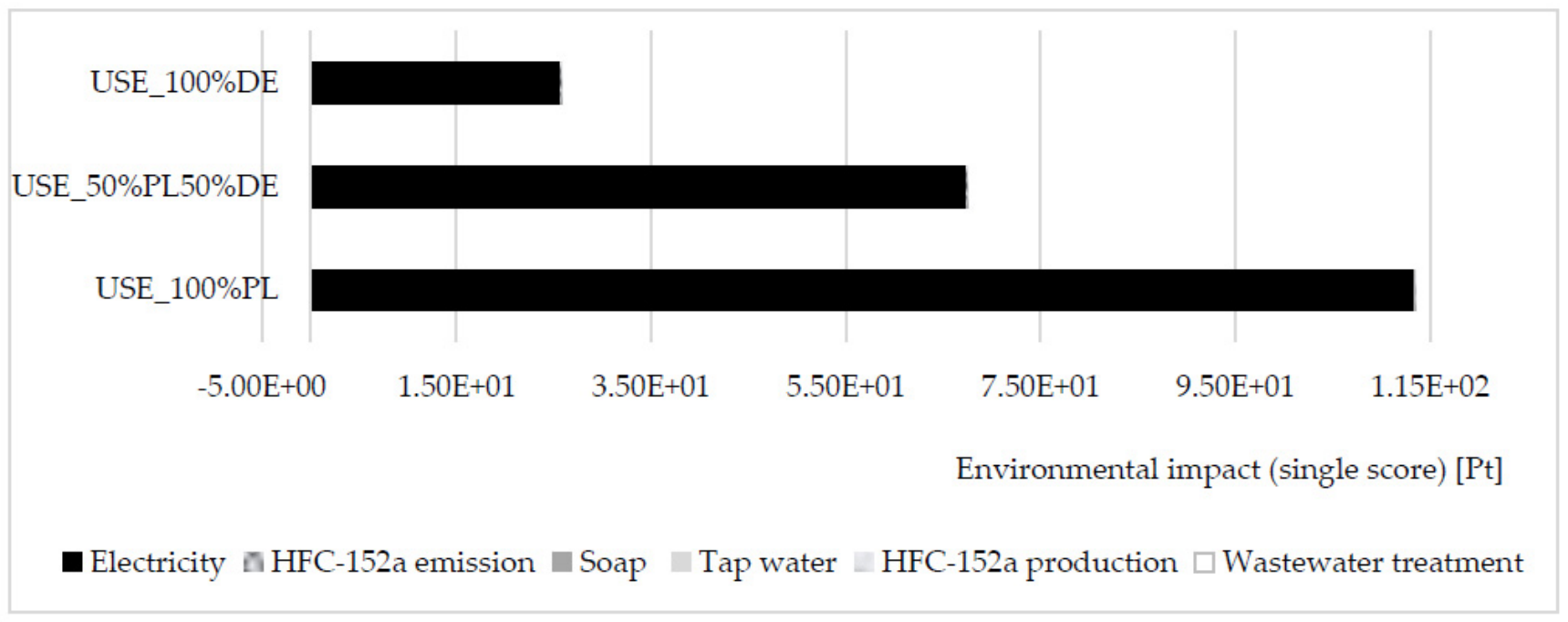

Figure 5. Environmental impact of the life cycle stage Use (USE) per 1 refrigerator $(25.827 \mathrm{Pt}=100 \% \mathrm{DE}, 67.514 \mathrm{Pt}=50 \% \mathrm{PL} 50 \% \mathrm{DE}$, 113.496 Pt $=100 \%$ PL, decrease by $77 \%$ ). 


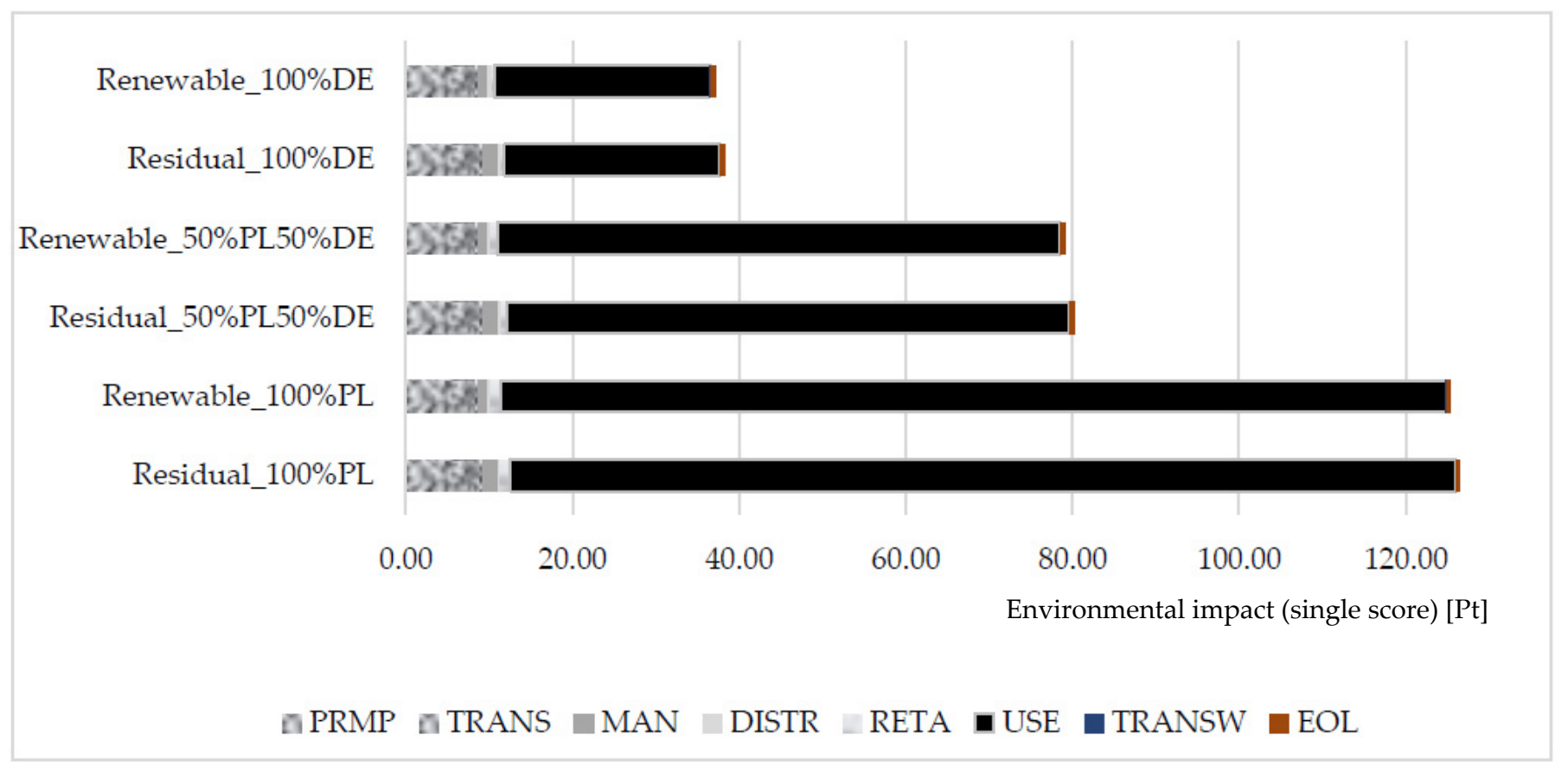

Figure 6. Environmental impact of the full life cycle of 1 refrigerator in different scenarios.

Table 4. Environmental impact (single score) of the full life cycle of analysed refrigerator modelled in different scenarios (ReCiPe, endpoint).

\begin{tabular}{|c|c|c|c|c|c|c|c|c|c|c|}
\hline & PRMP & TRANS & MAN & DISTR & RETA & USE & TRANSW & EOL & TOTAL & Unit \\
\hline \multirow{2}{*}{$\begin{array}{l}\text { Residual } \\
100 \% \mathrm{PL}\end{array}$} & 8.95 & 0.31 & 1.79 & 0.28 & 1.20 & 113.50 & 0.05 & 0.36 & 124.44 & $\mathrm{Pt}$ \\
\hline & 7.08 & 0.25 & 1.41 & 0.22 & 0.95 & 89.77 & 0.04 & 0.28 & 100 & $\%$ \\
\hline \multirow{2}{*}{$\begin{array}{c}\text { Renewable } \\
100 \% \text { PL }\end{array}$} & 8.33 & 0.31 & 1.23 & 0.28 & 1.20 & 113.50 & 0.05 & 0.36 & 125.25 & $\mathrm{Pt}$ \\
\hline & 6.65 & 0.25 & 0.98 & 0.23 & 0.95 & 90.61 & 0.04 & 0.29 & 100 & $\%$ \\
\hline \multirow{2}{*}{$\begin{array}{c}\text { Residual } \\
\text { 50\%PL50\%DE }\end{array}$} & 8.95 & 0.31 & 1.79 & 0.40 & 0.71 & 67.51 & 0.05 & 0.51 & 80.24 & $\mathrm{Pt}$ \\
\hline & 11.16 & 0.39 & 2.23 & 0.50 & 0.89 & 84.14 & 0.06 & 0.64 & 100 & $\%$ \\
\hline \multirow{2}{*}{$\begin{array}{c}\text { Renewable } \\
\text { 50\%PL50\%DE }\end{array}$} & 8.33 & 0.31 & 1.23 & 0.40 & 0.71 & 67.51 & 0.05 & 0.51 & 79.06 & $\mathrm{Pt}$ \\
\hline & 10.54 & 0.40 & 1.56 & 0.51 & 0.90 & 85.40 & 0.06 & 0.65 & 100 & $\%$ \\
\hline \multirow{2}{*}{$\begin{array}{l}\text { Residual } \\
100 \% \mathrm{DE}\end{array}$} & 8.95 & 0.31 & 1.79 & 0.52 & 0.27 & 25.83 & 0.05 & 0.66 & 39.838 & $\mathrm{Pt}$ \\
\hline & 23.32 & 0.81 & 4.66 & 1.36 & 0.71 & 67.29 & 0.12 & 1.72 & 100 & $\%$ \\
\hline \multirow{2}{*}{$\begin{array}{c}\text { Renewable_ } \\
100 \% \text { DE }\end{array}$} & 8.33 & 0.31 & 1.23 & 0.52 & 0.27 & 25.83 & 0.05 & 0.66 & 37.20 & $\mathrm{Pt}$ \\
\hline & 22.39 & 0.84 & 3.31 & 1.41 & 0.73 & 69.42 & 0.13 & 1.78 & 100 & $\%$ \\
\hline
\end{tabular}

In the first life cycle stage-production of raw materials and packaging - the transition from the residual mix to renewable at the aluminium, copper, and steel suppliers resulted in a decrease in the single score by $7 \%$ (from $8.952 \mathrm{Pt}=$ residual, $8.329 \mathrm{Pt}=$ renewable, Figure 1). This improvement was gained mainly because of the change in the electricity mix to be used during production of the liquid primary aluminium. If the refrigerator manufacturer used renewable energy at the Manufacturing of refrigerator stage, it contributed to a $20 \%$ decrease in the result for this stage (Figure 2).

The remaining life cycle stages exhibit a clear difference between the different options. The indicator result for distribution is $47 \%$ lower for national distribution in Poland, which results from the transport distance being twice as short as to Germany $(0.508 \mathrm{Pt}=100 \% \mathrm{DE}$, $0.388 \mathrm{Pt}=50 \% \mathrm{PL} 50 \% \mathrm{DE}, 0.268 \mathrm{Pt}=100 \% \mathrm{PL}$ ), see Figure 3 . 
Only the consumption of electric power is taken into account in the retail sale. The environmental impact of this stage is $77 \%$ lower when the refrigerator is sold $100 \%$ in Germany compared to the sales scenario in Poland (Figure 4). The situation is similar for the operation stage (Figure 5). Over the 10 years of refrigerator operation, electrical power consumption is responsible for almost all the environmental impact of this stage. The index score decreases by $77 \%$ when changing the operation country $(25.827 \mathrm{Pt}=100 \% \mathrm{DE}$, $67.514 \mathrm{Pt}=50 \% \mathrm{PL} 50 \% \mathrm{DE}, 113.496 \mathrm{Pt}=100 \% \mathrm{PL}$ ).

Figure 6 presents the results of the environmental impact for the whole life cycle. The lowest indicator result of $38.94 \mathrm{Pt}$ was obtained for the renewable_100\%DE scenario (suppliers of steel, aluminium, and copper use renewable energy, refrigerator manufacturer uses renewable energy, and the refrigerator is sold and operated 100\% in Germany), while the highest indicator result $(127.38 \mathrm{Pt})$ was obtained for the residual_100\%PL scenario (steel, aluminium and copper suppliers, as well as refrigerator manufacturer, use countryspecific real mix energy, and the refrigerator is sold and used 100\% in Poland).

\section{Discussion}

Life-cycle-based environmental performance is becoming an increasingly relevant element of products' strategy and their competitiveness on the market. Energy efficiency seems to be one of the most important areas for the potential improvement of performance. In our case study, an electric product was selected. Energy (electric or heat) was consumed at every stage of the refrigerator's life cycle. Similar to many other types of electric and electronic equipment, in our LCA study, the use stage and the use-related electricity consumption were identified as the most relevant elements. This means that the environmental hot spots are located in the background system which is not run by the producer and which is usually modelled with generic inventory data (e.g., country-specific consumption electricity mixes). In our case study, the same refrigerator was assumed to be distributed, retailed, exploited, and disposed of in scenarios assuming different sales structures (100\% PL, 50\% PL 50\% DE, 100\% DE). The electricity used during the downstream stages was modelled with the supplier electricity mix for each of the countries. Environmentally speaking, the mix is much better in the case of Germany than Poland. The comparison of the results presented in Table 3 shows that the environmental impact of generating $1 \mathrm{kWh}$ of energy with the residual mix for Poland is more than twice as high as the energy generation with the residual mix for Germany $(0.018 \mathrm{Pt} / \mathrm{kWh}$ residual mix for Germany and $0.038 \mathrm{Pt} / \mathrm{kWh}$ residual mix for Poland). However, if we look at the analogous results for the supplier mix, the difference is even greater, more than four-fold (0.008 Pt/kWh supplier mix for Germany and $0.036 \mathrm{Pt} / \mathrm{kWh}$ supplier mix for Poland). This means that, for every $1 \mathrm{kWh}$ of energy consumed at individual after-sales stages in Germany, the indicator is more than four times lower compared to the scenario in Poland.

In our example, it is the choice of the sales structure and the target market that turned out to be the most powerful driver for the LCA results. As presented in Table 4 the value of the single score for the use stage is $113.5 \mathrm{Pt}, 67.51 \mathrm{Pt}$, and $25.83 \mathrm{Pt}$ for sale in Poland (100\% PL), Poland and Germany (50\% PL and 50\% DE), and Germany (100\% DE), respectively. The decrease in the single score is $40 \%$ and $77 \%$. In practice, this may mean a significantly different life cycle environmental performance, even for products having very similar technical specifications and upstream impacts. From the perspective of the obtained results, the following question by the producer may be recognised as possible and justified: "is it better to me, for environmental reasons, to export my energy-related and durable products abroad, to be used in countries with better national electricity consumption mixes than to sell it on the domestic market where the worst national electricity mix exists?". From a purely environmental point of view, the reasonable answer seems to be "yes". The improvement of national electricity mixes is a very welcome but long-term process which takes decades rather than years. This means that the creation of a long-term product strategy and sales structure may also be important from the environmental perspective. Often, there is room to improve the technical parameters and energy efficiency of products 
by ecodesign. However, the resulting reduction in the use-related electricity consumption may not be enough to compensate the differences between national electricity mixes.

After the use stage is the production of construction materials and packaging (PRMP), which has the second highest environmental score $(8.95 \mathrm{Pt}$ for the residual and $8.33 \mathrm{Pt}$ for the renewable electricity model). The score for this stage is a few times lower than the environmental impact caused during use. The change from fossil to renewable energy during the production of aluminium ingot, copper, and low-alloyed steel reduced the single score by $7 \%$ (Figure 1). This resulted mainly from the change made in the life cycle of aluminium. The environmental benefit is gained mostly by using hydro power instead of the residual electricity in the production of primary liquid aluminium (assumed to be located in Germany). A total of $2.07 \mathrm{~kg}$ of liquid aluminium is used to produce $2.2 \mathrm{~kg}$ of aluminium ingot per refrigerator. Production of the liquid aluminium consumes $33 \mathrm{kWh}$ and generates an environmental impact equal to $0.559 \mathrm{Pt}$ for the residual and $0.0188 \mathrm{Pt}$ for the hydro power scenarios, respectively. This means that the environmental benefit resulting from the change in electricity model applied during the production of the liquid aluminium is $87 \%$ of the total benefit calculated for the PRPM stage. From the entire life cycle perspective, this benefit seems to be much smaller because the clear dominance of the relevance of the use stage of the PRMP increases with decrease in the single score value for the use stage (as a result of the sales shift from Poland to Germany). In the case of full sale of the product in Germany (Table 4, scenario 100\% DE), the change in the energy model during liquid aluminium production reduces the total single score for the entire life cycle by $1.35 \%$. The change in energy in the production of metals did not result in a significant change to the final indicator score, due to the fact that the main sources of impact include the emissions of dust and acidifying substances associated with the processing of metals, the extraction of raw materials (crude iron, ferrochrome, ferronickel, molybdenum), and the treatment of waste.

It is worth noting, however, that these results only apply to the specific product. If we analyse passive products, but with highly energy-intensive upstream and manufacturing processes [34], the transition of suppliers or manufacturers to renewable energy could prove crucial from a life cycle perspective. The situation for energy-powered equipment with a short lifetime and/or significantly reduced energy consumption at the use stage (e.g., mobile phones) may be analogous. In this case, the importance of the production stages may increase significantly at the expense of a decrease in the share at the use stage.

\section{Conclusions}

The consumption of heat or electricity occurs at every stage of the product life cycle and may be an important source of environmental impact. In the paper, an LCA case study for a refrigerator is presented. The following conclusions may be formulated from the analysis:

- From the life cycle perspective, not only may differences in national electricity systems between countries turn out to be important, but equally significant may be the choice between different types of mixes for a certain country. In our study, three countries were selected: Austria, Germany, and Poland. At the current time, they represent completely different situations. Austria has no residual mix, as all electricity is tracked. Germany has visibly different residual and supplier mixes because almost $60 \%$ of electricity is tracked. Poland has very similar residual and supplier mixes, as only a very small portion of electricity is tracked currently.

- The downstream stages (distribution, retail, use, and end of life) often belong to a background system and are modelled with generic inventory data. Because of the high environmental relevance of the operation stage, the choice of a certain type of electricity mix to be used to model the energy consumption in the downstreams should be recognised as an important factor in LCA calculations for energy-related durable products. 
- The choice of the national electricity mix may be important also for upstream and core stages, especially in the case of passive products (not powered by energy). However, access to primary data may be easier for these processes, so it is probable that, instead of using national mixes, LCA practitioners may apply data for a specific technology of energy generation.

- If more renewable energy sources are applied to produce the electricity consumed during operation, the relevance of the use stage is reduced. In our case study, this was very clear in the scenario $50 \% \mathrm{PL} 50 \% \mathrm{DE}$, where the share of production of raw materials and packaging increased from $7 \%$ to $22 \%$, and, at the same time, the share of the use of the refrigerator decreased from $89 \%$ to $26 \%$.

- If EEE products are to be sold (and used) on the markets in countries with clearly different electricity systems, they may have very different life cycle environmental performance. So, in the case of this sort of product, the target market and sales structure should also be seen as important factors in creating the product strategy and impacting its environmental competitiveness. In this light, improving national energy mixes and increasing the share of energy covered by credible and reliable tracking systems should be considered a priority, not only from the point of view of national climate policy but also from the perspective of individual enterprises.

Supplementary Materials: The following are available online at https: / www.mdpi.com/article/ 10.3390/en14175350/s1, Table S1: Scenarios used in the calculations for particular life cycle stages of refrigerator, Table S2: The impact assessment results (single score) for a single life cycle stage-Production of Raw Materials and Packaging (PRMP), Table S3: The impact assessment results (single score) for a single life cycle stage-Transport of raw materials and packaging (TRANS), Table S4: The impact assessment results (single score) for a single life cycle stage-Manufacturing (MAN), Table S5: The impact assessment results (single score) for a single life cycle stage—Distribution (DISTR), Table S6: The impact assessment results (single score) for a single life cycle stage-Retail (RETA), Table S7: The impact assessment results (single score) for a single life cycle stage-Use (USE), Table S8: The impact assessment results (single score) for a single life cycle stage-Transport of waste (TRANSW), Table S9: The impact assessment results (single score) for a single life cycle stage—End of Life (EOL).

Author Contributions: Conceptualization, A.L. and P.K.; methodology, A.L. and K.J.-L.; software, A.L. and K.J.-L.; validation, M.Z.; formal analysis, A.L.; investigation, A.L.; resources, A.L. and K.J.-L.; data curation, A.L.; writing-original draft preparation, A.L.; writing-review and editing P.K. and K.J.-L.; visualization, M.Z.; supervision, A.L.; project administration, P.K.; funding acquisition, P.K. and M.Z. All authors have read and agreed to the published version of the manuscript.

Funding: This research received no external funding.

Institutional Review Board Statement: Not applicable.

Informed Consent Statement: Not applicable.

Data Availability Statement: The analysis has been made mostly with using the inventory data taken from the ecoinvent database 3.6, included in the LCA software. In some extent, virtual data has been also used.

Conflicts of Interest: The authors declare no conflict of interest. 


\begin{tabular}{ll} 
Abbreviations & \\
AIB & Association of Issuing Bodies \\
AT & Austria \\
DE & Germany \\
DISTR & Distribution \\
EEE & Electric and Electronic Equipment \\
EOL & End of Life \\
EUR & Europe \\
EPD & Environmental Product Declaration \\
GOO & Guarantee of Origin \\
HFC & $1,1-$ Difluoroethane \\
LCA & Life Cycle Assessment \\
LCI & Life Cycle Inventory \\
LCIA & Life Cycle Impact Assessment \\
MAN & Manufacturing \\
PEF & Product Environmental Footprint \\
PL & Poland \\
PRMP & Production of Raw Materials and Packaging \\
Pt & point \\
RETA & Retail \\
TRANS & Transport \\
TRANSW & Transport of Waste \\
$100 \% P L$ & $100 \%$ of sale, use and end of life located in Poland \\
$50 \% P L 5 \% D E$ & $50 \%$ of sale, use and end of life located in Poland and 50\% in Germany \\
$100 \%$ DE & $100 \%$ of sale, use and end of life located in Germany \\
& \\
\hline
\end{tabular}

\section{References}

1. Ekvall, T. Attributional and Consequentia Life Cycle Assessment. Available online: https://www.intechopen.com/chapters / 69212 (accessed on 28 July 2021).

2. $\quad$ Finnveden, G.; Hauschild, M.Z.; Ekvall, T.; Guinee, J.; Heijungs, R.; Hellweg, S.; Koehler, A.; Pennington, D.; Suh, S. Recent developments in Life Cycle Assessment. J. Environ. Manag. 2009, 91, 1-21. [CrossRef] [PubMed]

3. Frischknecht, R.; Stucki, M. Scope-dependent modelling of electricity supply in life cycle assessments. Int. J. Life Cycle Assess. 2010, 15, 806-816. [CrossRef]

4. Vandepaer, L.; Treyer, K.; Mutel, C.; Bauer, C.; Amor, B. The integration of long-term marginal electricity supply mixes in the ecoinvent consequential database version 3.4 and examination of modelling choices. Int. J. Life Cycle Assess. 2019, 24, 1409-1428. [CrossRef]

5. Schmidt, J.H.; Thrane, M.; Merciai, S.; Dalgaard, R. Inventory of Country Specific Electricity in LCA-Consequential and Attributional Scenarios. Methodology Report v2. 2.-0 LCA Consultants. 2011. Available online: http://www.lca-net.com/ projects / electricity_in_lca/ (accessed on 28 July 2021).

6. Jones, C.; Gilbert, P.; Raugei, M.; Mander, S.; Leccisi, E. An approach to prospective consequential life cycle assessment and net energy analysis of distributed electricity generation. Energy Policy 2017, 100, 350-358. [CrossRef]

7. Gaska, K.; Generowicz, A.; Ocłon, P.; Stelmach, S. Location of the waste incineration plant with particular emphasis on the environmental criteria. J. Clean Prod. 2021, 303, 126887. [CrossRef]

8. Rossi, B.; Marique, A.F.; Reiter, S. Life-cycle assessment of residential buildings in three different European locations, case study. Build. Environ. 2012, 51, 402-407. [CrossRef]

9. Olindo, R.; Schmitt, N.; Vogtländer, J. Life Cycle Assessments on Battery Electric Vehicles and Electrolytic Hydrogen: The Need for Calculation Rules and Better Databases on Electricity. Sustainability 2021, 13, 5250. [CrossRef]

10. Environmental Product Declarations. Available online: https:/ / www.environdec.com/home (accessed on 7 June 2021).

11. Environmental Footprints of Products and Organisations. Available online: https://ec.europa.eu/environment/eussd/smgp/ ef_transition.htm (accessed on 7 June 2021).

12. Monfared, B.; Furberg, R.; Palm, P. Magnetic vs. vapor-compression household refrigerators: A preliminary comparative life cycle assessment. Int. J. Refrig. 2014, 42, 69-76. [CrossRef]

13. Gallego-Schmid, A.; Mendoza, J.M.F.; Jeswani, H.K.; Azapagic, A. Life cycle environmental impacts of vacuum cleaners and the effects of European regulation. Sci. Total Environ. 2016, 559, 192-203. [CrossRef] [PubMed]

14. Landi, D.; Consolini, A.; Germani, M.; Favi, C. Comparative life cycle assessment of electric and gas ovens in the Italian context: An environmental and technical evaluation. J. Clean Prod. 2019, 221, 189-201. [CrossRef]

15. Asdrubali, F.; Grazieschi, G. Life cycle assessment of energy efficient buildings. Energy Rep. 2020, 6, 270-285. [CrossRef] 
16. Ali, A.A.M.; Negm, A.M.; Bady, M.F.; Ibrahim, M.G.E. Environmental life cycle assessment of a residential building in Egypt: A case study. Proc. Technol. 2015, 19, 349-356. [CrossRef]

17. Eder, P.; Delgado, L. Environmental Impact of Products (EIPRO) Analysis of the Life Cycle Environmental Impacts Related to the Final Consumption of the EU-25 IPTS/ESTO Project. 2006. Available online: https://op.europa.eu/en/publication-detail/- / publication/3b4b06b7-4bc0-4350-a20b-accdc70d1d94/language-en (accessed on 5 June 2021).

18. Dettling, J.; Tu, Q.; Faist, M.; DelDuce, A.; Mandlebaum, S. Assessing the Environmental Benefits of Plant-Based Dietary Choices Through: A Comparison of Meal Choices, and a Comparison of Meat Products and Morning Star Farms ${ }^{\circledR}$ Veggie Products. 2016. Available online: https://www.morningstarfarms.com/content/dam/NorthAmerica/morningstarfarms/pdf/ MSFPlantBasedLCAReport_2016-04-10_Final.pdf (accessed on 5 June 2021).

19. Usva, K.; Sinkko, T.; Silvenius, F.; Riipi, I.; Heusala, H. Carbon and water footprint of coffee consumed in Finland-Life cycle assessment. Int. J. Life Cycle Assess. 2020, 25, 1976-1990. [CrossRef]

20. González-García, S.; Castanheira, E.G.; Dias, A.C.; Arroja, L. Environmental life cycle assessment of a dairy product: The yoghurt. Int. J. Life Cycle Assess. 2013, 18, 796-811. [CrossRef]

21. Smetana, S.; Mathys, A.; Knoch, A.; Heinz, V. Meat alternatives: Life cycle assessment of most known meat substitutes. Int. J. Life Cycle Assess. 2015, 20, 1254-1267. [CrossRef]

22. Laitala, L.; Klepp, I.G.; Henry, B. Use phase of apparel: A Literature review for Life Cycle Assessment with focus on wool. In SIFO Professional Report No. 6-2017; Oslo, Norway, 2017; Available online: https://oda.oslomet.no/oda-xmlui/bitstream/handle/20.5 00.12199/5343/FR\%206-2017\%20-\%20A\%20literature\%20review\%20for\%20Life\%20Cycle\%20Assesement \%20with\%20focus\% 20on\%20wool.pdf?sequence=1\&isAllowed=y (accessed on 28 July 2021).

23. Zampori, L.; Pant, R. Suggestions for Updating the Product Environmental Footprint (PEF) Method; Publications Office of the European Union: Luxembourg, 2019; Available online: https:/ / eplca.jrc.ec.europa.eu/permalink/PEF_method.pdf (accessed on 7 June 2021).

24. ISO 14044 Environmental Management_Life Cycle Assessment_Requirements and Guidelines; International Organization for Standardization: Geneva, Switzerland, 2006.

25. Huijbregts, M.A.J.; Steinmann, Z.J.J.; Elshout, P.M.F.; Stam, G.; Verones, F.; Vieira, M.; Zijp, M.; Hollander, A.; van Zelm, R. ReCiPe2016: A harmonised life cycle impact assessment method at midpoint and endpoint level. Int. J. Life Cycle Assess. 2017, 22, 138-147. [CrossRef]

26. Ecoinvent. Available online: https://www.ecoinvent.org/database/older-versions/ecoinvent-36/ecoinvent-36.html (accessed on 28 July 2021).

27. Saternus, M. The primary aluminium technology, production, prospects. Rudy Met. 2006, 6, 316-325.

28. Aho, J.; Ali-Raatikainen, A.; Leino, K.; Heinonen, U. Screening Carbon Footprint for Aluminium Wine Packaging Final Report Gaia Consulting. 2019. Available online: https://www.omsystembolaget.se/globalassets/pdf/hallbarhet/alko-aluminiumbottle-co2-calculation-final-report.pdf (accessed on 29 July 2021).

29. Environmental Profile Report for the European Aluminum Industry. Life Cycle Inventory Data for Aluminium Production and Transformation processes in Europe. Report of European Aluminum Association. 2013. Available online: https: / / www.europeanaluminium.eu/media/1329/environmental-profile-report-for-the-european-aluminium-industry.pdf (accessed on 29 July 2021).

30. World Steel in Figures. Report of World Steel Association Report. 2020. Available online: https://www.worldsteel.org/steel-bytopic/statistics/World-Steel-in-Figures.html (accessed on 29 July 2021).

31. Gajdzik, B. Analysis and prediction of steel production technology trends in Poland, Europe and in the world. Pr. Inst. Metal. Żelaza 2017, 69, 58-67.

32. DIRECTIVE (EU). 2018/2001 of the European Parliament and of the Council of 11 December 2018 on the Promotion of the Use of Energy from Renewable Sources. Available online: https:/ / eur-lex.europa.eu/legal-content/EN/TXT/PDF/?uri=CELEX: 32018L2001\&from=EN (accessed on 15 June 2021).

33. Association of Issuing Bodies. European Residual Mixes Results of the Calculation of Residual Mixes for the Calendar Year 2020 AIB Report Version 1.0. 31 May 2021. Available online: https:/ / www.aib-net.org/facts/european-residual-mix (accessed on 7 June 2021).

34. Piotrowska, K.; Kruszelnicka, W.; Bałdowska-Witos, P.; Kasner, R.; Rudnicki, J.; Tomporowski, A.; Flizikowski, J.; Opielak, M. Assessment of the Environmental Impact of a Car Tire throughout Its Lifecycle Using the LCA Method. Materials 2019, $12,4177$. [CrossRef] [PubMed] 